\section{EKONOMI MANAGERIAL \\ IImu Ekonomi Mikro Terapan dalam Keputusan Bisnis}

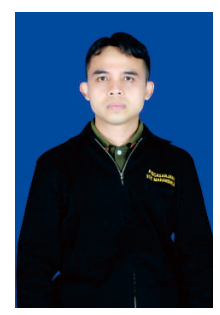

Ekonomi Manajerial merupakan disiplin ilmu yang mempelajari tentang implementasi dari ilmu ekonomi terutama ilmu ekonomi mikro serta perangkat analisis ilmu dalam pengambilan keputusan seperti matematika, statistika dan ekonometrika untuk memecahkan masalah yang dihadapi oleh seorang manajer dalam pengambilan kebijakan manajerial. Buku ini terdiri dari 13 bab yang membahas tentang:

- Ruang lingkup ekonomi managerial \& Optimasi Ekonomi

- Permintaan, penawaran dan keseimbangan pasar, analisis elastisitas dalam keputusan managerial \& penaksiran Fungsi Permintaan

- Analisis Perilaku Konsumen

- Analisis perilaku produksi \& penaksiran dan peramalan serta analisis biaya produksi

- Struktur Pasar \& praktek dalam penetapan harga

- Pengambilan keputusan dalam ketidakpastian

- Keputusan penganggaran modal dan investasi

Buku ini juga disertai dengan latihan soal dengan penghitungan baik secara manual maupun dengan menggunakan software agar memperkaya pemahaman pembaca dengan bahasa yang mudah dipahami, sistematis, dikemas menarik serta pembahasan yang rinci dan sederhana sehingga dapat dipelajari oleh mahasiswa baik Akuntansi ataupun Management.

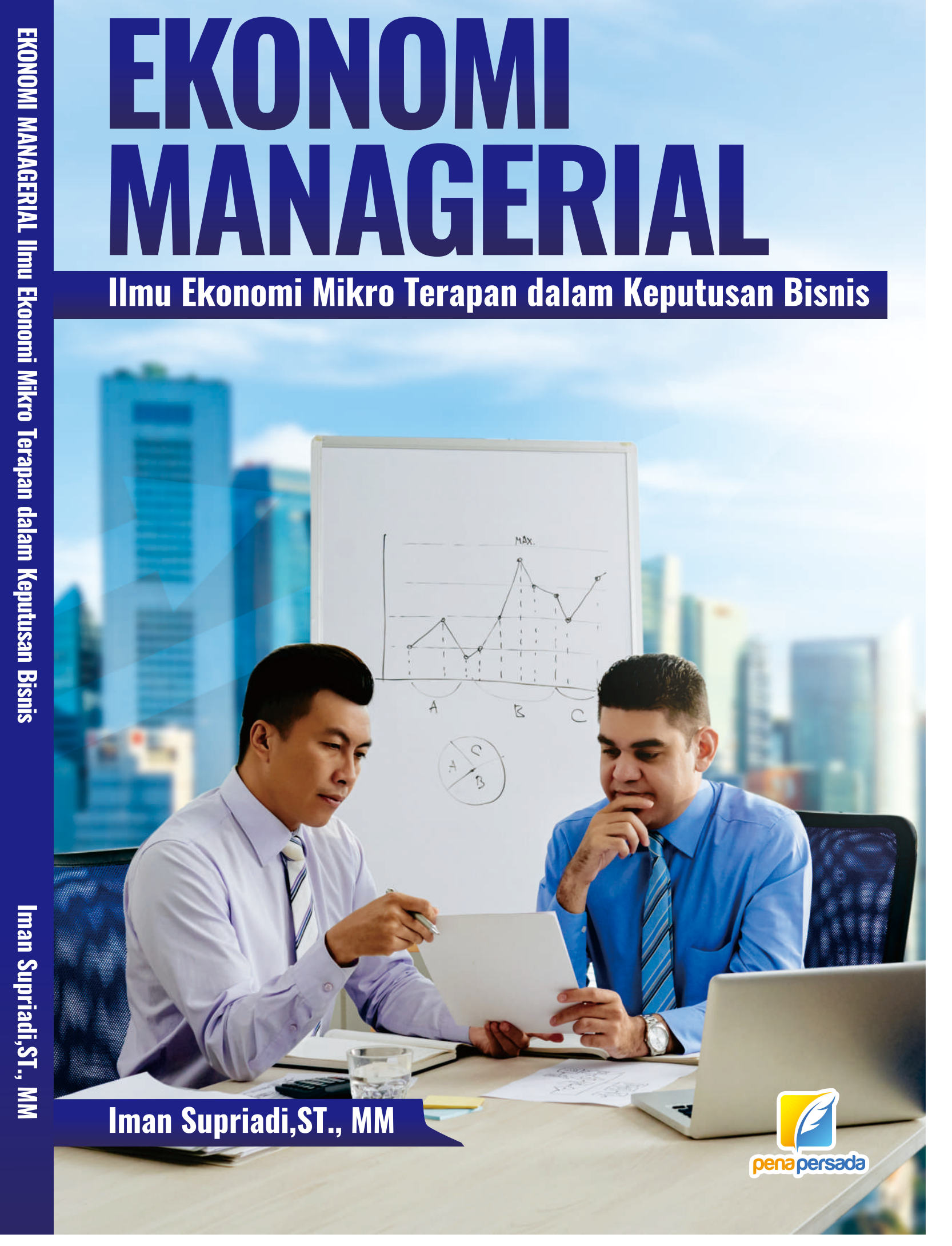




\section{EKONOMI MANAGERIAL}

Ilmu Ekonomi Mikro Terapan dalam Keputusan Bisnis

Iman Supriadi,ST., MM

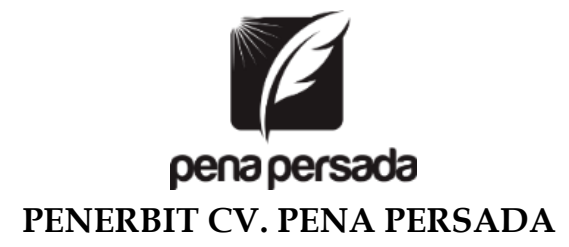




\title{
EKONOMI MANAGERIAL \\ Ilmu Ekonomi Mikro Terapan dalam Keputusan Bisnis
}

\author{
Penulis: \\ Iman Supriadi,ST., MM \\ ISBN : 978-623-315-437-6
}

Design Cover :

Retnani Nur Briliant

Layout :

Eka Safitry

\section{Penerbit CV. Pena Persada}

Redaksi :

Jl. Gerilya No. 292 Purwokerto Selatan, Kab. Banyumas

Jawa Tengah

Email : penerbit.penapersada@gmail.com

Website : penapersada.com Phone : (0281) 7771388

Anggota IKAPI

All right reserved

Cetakan pertama : 2021

Hak Cipta dilindungi oleh undang-undang. Dilarang memperbanyak karya tulis ini dalam bentuk apapun tanpa izin penerbit 


\section{KATA PENGANTAR}

Bismillahirrahmanirrahim, Assalamu'alaikum warahmatullahi wabarakatuh.

Segala puji bagi Allah SWT. yang telah menolong hambanya menyelesaikan buku ini dengan penuh kemudahan. Tanpa pertolongannya, mungkin saya selaku penulis tidak akan sanggup menyelesaikan buku ini dengan baik.

Buku ini disusun agar pembaca dapat mengetahui "Ekonomi Managerial, Ilmu ekonomi mikro terapan dalam keputusan bisnis" yang kami sajikan berdasarkan literatur dari berbagai sumber. Buku Ekonomi Managerial ini merupakan media penting yang perlu diketahui oleh para pembaca yang ingin mempelajari hal hal yang berkaitan dengan ilmu ekonomi mikro terapan agar dalam pengambilan keputusan managerial dapat sesuai dengan yang diharapkan.

Penulis ingin mengucapkan banyak terima kasih kepada kedua orang tua, guru guru yang telah membimbing hingga terselesaikannya buku Ekonomi Managerial ini. Terlebih lagi penulis ingin mengucapkan banyak terima kasih kepada penulis senior yaitu Ari Darmawan, Dr. S.AB, M.AB Dosen Fakultas Ekonomi Universitas Brawijaya Malang. Karena dari modul modul beliau penulis termotivasi untuk bisa menulis buku Ekonomi Managerial ini. Semoga buku ini dapat member wawasan kepada pembaca. Penulis menyadari kalau buku ini memiliki kelebihan dan banyak kekurangan. Untuk itu, saran dan kritik mohon disampaikan agar kedepan jauh lebih baik. Terima kasih.

Wassalamu'alaikum warahmatullahi wabarakatuh

Sidoarjo, 24 Mei 2021

Penulis

Iman Supriadi,ST., MM 


\section{DAFTAR ISI}

KATA PENGANTAR ................................................................. iii

DAFTAR ISI ..............................................................................iv

BAB I RUANG LINGKUP EKONOMI MANAGERIAL ..................1

1.1 Konsep Ekonomi.................................................................... 3

1.2 Konsep Sumber Daya ......................................................... 4

1.3 Definisi Ekonomi Managerial ..........................................6

1.4 Hubungan ekonomi managerial dengan ilmu ekonomi lainnya .......................................................................

1.5 Prinsip-prinsip Ekonomi Managerial .............................. 10

1.6 Teori Perusahaan ............................................................. 15

1.7 Analisis Present Value ..................................................... 17

1.8 Pengukuran laba dan biaya kesempatan.......................... 22

1.9 Pengukuran profitabilitas perusahaan ............................. 25

1.10 Perbedaan profitabilitas dari berbagai perusahaan........29

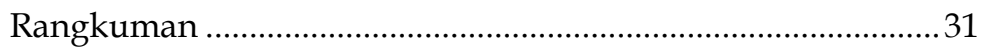

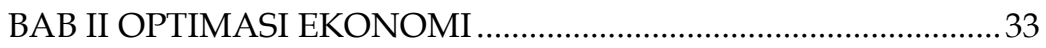

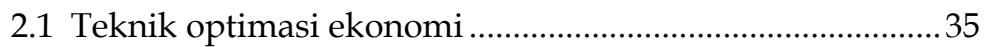

2.2 Optimisasi ekonomi tanpa kendala....................................39

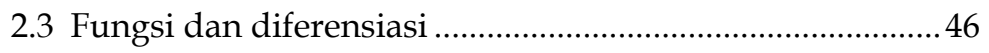

2.4 Turunan Fungsi........................................................... 47

2.5 Menentukan maksimasi dan minimasi dengan kalkulus .50

2.6 Memaksimumkan fungsi dengan banyak variabel...........56

2.7 Optimisasi ekonomi dengan kendala .................................58

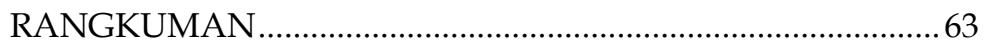


BAB III PERMINTAAN, PENAWARAN DAN KESEIMBANGAN

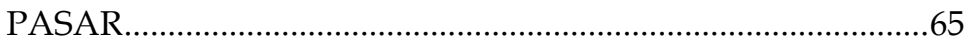

3.1 Teori Permintaan ..........................................................66

3.2 Fungsi Permintaan ......................................................67

3.3 Kurva Permintaan ................................................................81

3.4 Pergerakan dan Pergeseran Kurva Permintaan.................84

3.5 Teori Penawaran ................................................................86

3.6 Fungsi Penawaran..............................................................87

3.7 Kurva Penawaran..............................................................95

3.8 Pergerakan dan pergeseran kurva penawaran ..................98

3.9 Harga keseimbangan pasar .............................................100

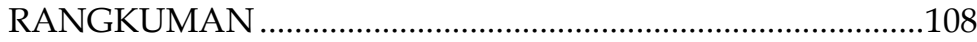

\section{BAB 4 ANALISIS ELASTISITAS DALAM KEPUTUSAN}

MANAGERIAL ...................................................................... 110

4.1 Pendahuluan..................................................................111

4.2 Koefisien elastisitas dengan rumus titik tengah ...............112

4.3 Elastisitas permintaan ........................................................115

4.4 Faktor faktor yang mempengaruhi elastisitas permintaan ...

4.5 Keterkaitan elastisitas permintaan dan hasil penjualan ..123

4.6 Elastisitas penawaran ................................................128

4.7 Faktor faktor yang mempengaruhi elastisitas penawaran....

4.8 Elastisitas Pendapatan ....................................................137

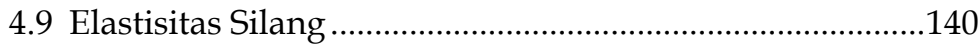

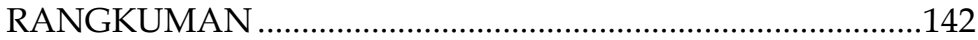


5.1 Penaksiran dan prakiraan permintaan

5.2 Metode penaksiran permintaan............................................ 148

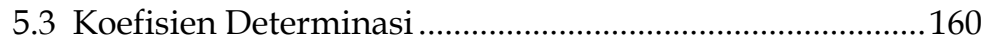

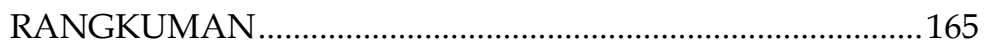

BAB 6 ANALISIS PERILAKU KONSUMEN …………..................167

6.1 Pengertian nilai guna (utility)..............................................169

6.2 Pendekatan nilai guna (utility) ……………………...........171

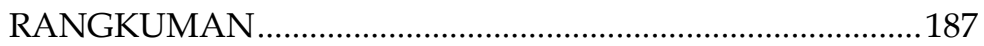

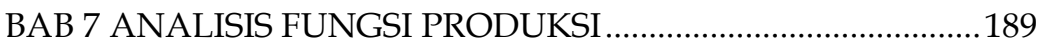

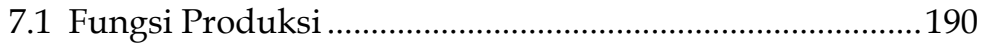

7.2 Fungsi produksi satu input satu output .............................192

7.3 Fungsi produksi dua input satu output ..............................201

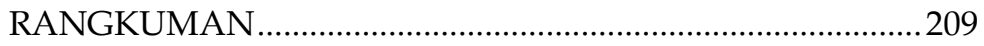

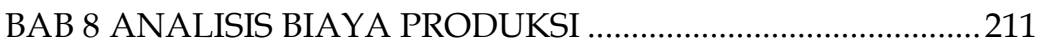

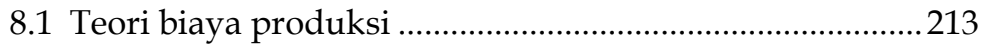

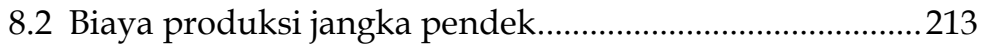

8.3 Biaya produksi jangka panjang.............................................217

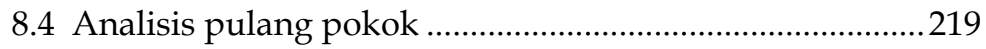

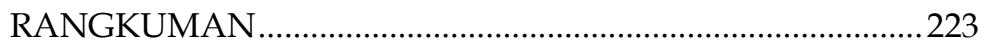

BAB 9 PENAKSIRAN DAN PERAMALAN BIAYA .......................225

9.1 Penaksiran fungsi biaya dan prakiraan biaya.....................227

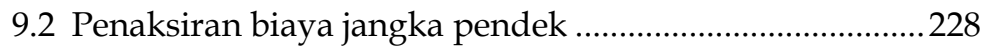

9.3 Penaksiran biaya jangka panjang ………….........................235

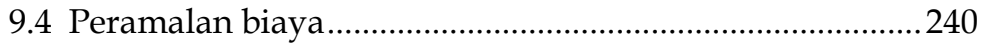

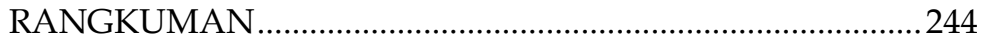




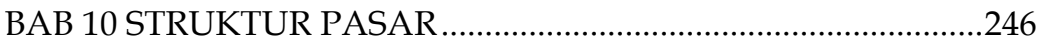

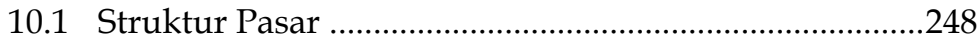

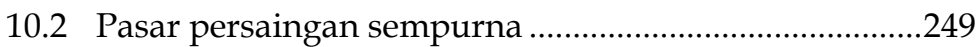

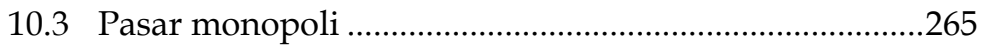

10.4 Pasar persaingan monopolistis .......................................278

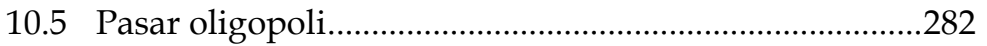

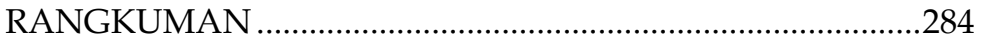

BAB 11 PRAKTEK PENETAPAN HARGA .......................................286

11.1 Metode dalam penetapan harga .......................................28

11.2 Penentuan harga dalam pasar yang mapan....................297

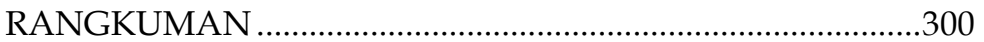

BAB 12 PENGAMBILAN KEPUTUSAN DALAM

KETIDAKPASTIAN ………………………………….............

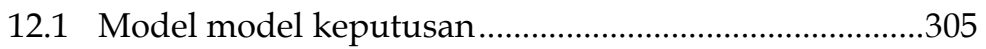

12.2 Ketidakpastian, probabilitas dan nilai harapan .............306

12.3 Sikap terhadap risiko ........................................................309

12.4 Langkah langkah pengambilan keputusan......................311

12.5 Metode penentuan keputusan …………………………....313

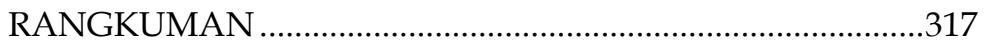

\section{BAB 13 KEPUTUSAN PENGANGGARAN MODAL DAN}

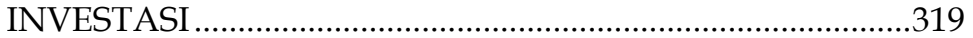

13.1 Metode penilaian investasi ...................................................320

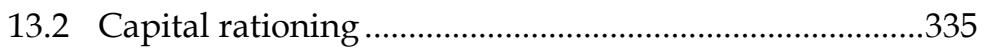

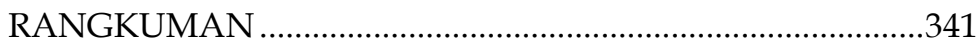

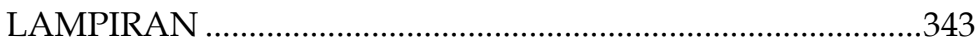

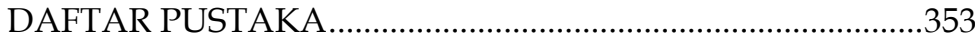




\section{EKONOMI MANAGERIAL}

Ilmu Ekonomi Mikro Terapan dalam Keputusan Bisnis 


\section{BAB I \\ RUANG LINGKUP EKONOMI \\ MANAGERIAL}

\section{Topik topik yang dibahas}

Beberapa topik yang dibahas dalam bab ini adalah sebagai berikut :

1. Konsep Ekonomi dan Sumber Daya

2. Hubungan ekonomi Managerial dengan ilmu ekonomi lainnya

3. Prinsip ekonomi Managerial

4. Teori Perusahaan

5. Pengukuran Laba dan profitabilitas

\section{Capaian pembelajaran}

Setelah mempelajari bab ini, pembaca diharapkan mampu :

1. Memahami dan menjelaskan pengertian, Sifat dan ruang lingkup ekonomi Managerial

2. Memahami dan menjelaskan teori perusahaan

3. Memahami dan menjelaskan peranan bisnis dalam masyarakat

4. Memahami pengukuran profitabilitas perusahaan dan perbedaan profitabilitas dari berbagai perusahaan 
Pada dasarnya teori ekonomi mampu diaplikasikan pada dunia bisnis. Keberadaan teori ekonomi mampu menjadi referensi dalam pengambilan keputusan bisnis. Teori ekonomi itu terdiri dari teori ekonomi makro dan ekonomi mikro. Teori ekonomi mikro mencakup seperangkat teori tentang pengambilan keputusan berdasarkan pada perilaku ekonomi seperti pemilik sumber daya, sistem perdagangan bebas dan konsumen individu. Sementara Teori Ekonomi makro mengkaji keadaan keseluruhan atau agregat dari kegiatan suatu perekonomian. Ilmu ekonomi makro membahas perilaku ekonomi agregat atau keluaran atau output nasional, pendapatan nasional, tingkat harga keseluruhan, serta laju inflasi secara umum. Teori tersebut tidak membuat analisis tentang kegiatan kegiatan yang dilakukan oleh seorang produsen, seorang konsumen atau seorang pemilik faktor produksi.Analisis ekonomi makro dititik beratkan pada pembahasan akibat dari keseluruhan tindakan pada konsumen, para produsen, pemerintah, dan kegiatan perdagangan luar negeri terhadap tingkat kegiatan perekonomian keseluruhan.

Salah satu teori ekonomi yang dapat diaplikasikan padadunia bisnis adalah teori ekonomi mikro. Penerapan teori ekonomimikro pada dunia bisnis dikenal sebagai ekonomi Managerial, atau juga dikenal sebagai ekonomi mikro terapan. Ekonomi Managerial menerapkan teori ekonomi mikro dengan tujuan untuk membantu manajer perusahaan atau pelaku bisnis di dalam mengambil keputusan. Matematika dan ekonometrika atau statistik dapat digunakan sebagai model keputusan yang bertujuan untuk menentukan langkah optimal perusahaan atau bisnis untuk mencapai tujuan Sebelum memahami lebih lanjut mengenai ekonomi Managerial, dipahami terlebih dahulu mengenai konsep ekonomi terlebih dahulu. 


\subsection{Konsep Ekonomi}

Dewasa ini jenis permasalahan ekonomi yang dihadapi negara negara di dunia hampir sama atau dengan istilah lain permasalahan global, yaitu meliputi masalah perdagangan internasional, defisit dan hutang, pengangguran dan inflasi,dan yang paling dominan di setiap negara adalah masalah kemiskinan. Ilmu ekonomi muncul sebagai upaya manusia dalam hal ini adalah ahli ekonomi untuk mencoba mengkaji dan memecahkan permasalahan diatas. Banyak definisi mengenai ilmu ekonomi, sebanyak ahli ekonomi yang mendefinisikannya. Dalm bab ini mereferensikan untuk mengutip definisi berikut ini "Ilmu Ekonomi atau economics merupakan studi tentang pemanfaatan sumberdaya yang langka atau terbatas untuk memenuhi kebutuhan manusia akan barang dan jasa yang cenderung tidak terbatas". Ekonomi dapat didefinisikan suatu ilmu yang mempelajari perilaku individu dan masyarakat untuk memilih untuk menggunakan sumber dayanya yang terbatas untuk dapat memenuhi kebutuhan individu dan masyarakat. Pada ilmu ekonomi, diasumsikan bahwa kebutuhan individu dan masyarakat adalah tidak terbatas, akan tetapi pada sisi yang lain individu dan masyarakat memiliki sumber daya yang terbatas.

Sumberdaya yang langka mengacu pada pengertian bahwa untuk memperoleh sumberdaya tadi perlu pengorbanan untuk mendapatkannya, kelangkaan atau scarcity sudah tidak terelakkan lagi dan menjadi pusat permasalahan ekonomi. Dengan demikian inti persoalan ekonomi adalah adanya kelangkaan,artinya sumberdaya yang tersedia tidak cukup untuk memenuhi keinginan manusia, atausumberdaya yang tersedia hanya untuk menghasilkan sebagian kecil barang dan jasa. Karena sumberdaya langka semua masyarakat menghadapi persoalan untuk memutuskan apa yang akan diproduksi, jumlah produksi, dan bagaimana memproduksinya serta bagaimana membagi produk tersebut diantara anggota 
masyarakat. Ketiga pertanyaan itu merupakan rangkuman dari masalah ekonomi. Pengambilan keputusan sangat berkaitan dengan masalah pilihan, kelangkaan mengharuskan adanya pilihan atau choice juga pilihan berarti adanya pengorbanan untuk mendapatkannya.

\subsection{Konsep Sumber Daya}

Sumber daya ekonomi merupakan seluruh alat yang dapat dipakai oleh manusia yang bertujuan untuk pemenuhan kebutuhan hidupnya. Seperti yang sudah diketahui, manusia adalah makhluk ekonomi sehingga tidak pernah merasa puas. Hal itu yang membuat manusia harus selalu berupaya memenuhi kebutuhannya. Manusia akan melakukan beragam usaha atau kegiatan untuk memenuhi kebutuhannya sendiri, hal ini merupakan bagian dari upaya untuk mencapai kesejahteraan dalam hidupnya. Inilah tujuan pokok dalam ekonomi yang dimiliki manusia. Dan pada hakikatnya kebutuhan itu cenderung tidak terbatas, sementara sumber daya yang ada dalam keadaan terbatas. Akibatnya supply dan demand menjadi terkendala. Maka manusia akan dihadapkan pada masalah ekonomi, yakni kelangkaan.

Secara matematis, supply dan demand mampu terdeteksi lebih awal jika saja kita mampu mengetahui berbagai faktor yang mempengaruhinya, sehingga persoalan kelangkaan dapat teratasi. Untuk dapat mengetahui beragam faktor yang mempengaruhinya, perlu menganal konsep dari kebutuhan dan kelangkaan itu sendiri. Sehingga dapat mengerucut menjadi sebuah faktor yang mempengaruhi kebutuhan dan kelangkaan itu sendiri.

Masalah ekonomi adalah kelangkaan dan semua pembahasan ilmu ekonomi berawal dari masalah ini. Jadi kelangkaan menunjukan ketidakseimbangan antara ketersediaan sumber daya dan kebutuhan manusia, sehingga dapat dikatakan jika kebutuhan dan kelangkaan erat kaitannya. Setidaknya ada 4 faktor penyebab terjadinya 
kelangkaan dalam ekonomi, yaitu ketersediaan barang dan jasa terbatas, sukar memperoleh barang dan jasa yang dibutuhkan, banyak orang yang membutuhkan, dan letak geografis.Dengan mengetahui faktor terjadinya kelangkaan maka ada beberapa upaya yang bisa dilakukan guna mengatasi masalah kelangkaan ini yaitu dengan pemanfaatan sumber daya alam secara efisien dan efektif, pendidikan dan pelatihan sumber daya manusia secara berkelanjutan, mengelola dan memberdayakan modal yang dimiliki.

Kelangkaan sumber daya dan mengharuskan individu dan masyarakat untuk mengambil pilihan untuk memilih kebutuhan yang diprioritaskan, maka berikut ini akan dijelaskan mengenai jenis sumber daya yang terdapat di sekitar kita. Secara umum, terdapat dua jenis sumber daya, yaitu:

1. Sumber daya yang terbatas

Merupakan sumber daya memerlukan suatu pengorbanan untuk memperolehnya, sehingga sumber daya ini dapat dikategorikan sebagai barang ekonomi atau barang yang memiliki nilai uang. Sumber daya terbatas umum sering disebut pula kelangkaan. Kelangkaan adalah di mana kita tidak memiliki sumber daya yang cukup untuk memuaskan keinginan manusia. Kelangkaan terjadi saat jumlah kebutuhan lebih besar dari alat pemuas kebutuhan atau sumber daya. Penyebab terjadinya kelangkaan antara lain perbedaan letak geografis, pertumbuhan penduduk, kemampuan produksi, perkembangan teknologi serta bencana alam. Adapun contoh dari sumber daya yang terbatas, antara lain yaitu tanah, tenaga kerja, modal, ketrampilan.

2. Sumber daya yang tidak terbatas

Merupakan sumber daya yang tidak memerlukan suatu pengorbanan untuk memperolehnya, sehingga sumber daya ini dapat dikategorikan sebagai barang bebas yaitu barang yang tidak memiliki nilai uang. Sumber daya alam tak terbatas juga disebut sumber daya 
alam yang dapat diperbaharui. Contoh dari sumber daya yang tidak terbatas, yaitu air dan udara. Konsep sumber yang tidak terbatas untuk saat ini, sifatnya adalah relatif, tergantung pada lokasi sumber daya tersebut berada. Apabila sumber daya tersebut berada di daerah pedesaan, maka dapat dikatakan sebagai sumber daya yang tidak terbatas. Sebaliknya, apabila sumber daya tersebut berada di daerah perkotaan, maka sumber daya tersebut tidak dapat dikatakan sebagai sumber daya yang tidak terbatas.

Berawal dari masalah pemenuhan kebutuhan serta kelangkaan inilah maka manusia melakukan berbagai kegiatan atau tindakan ekonomi guna memenuhi kebutuhannya. Setiap kegiatan ekonomi manusia juga dilatarbelakangi oleh motif ekonomi yaitu dorongan yang muncul dalam diri seseorang guna melakukan tindakan ekonomi. Dalam setiap kegiatan itu pula, manusia menerapkan prinsip ekonomi yang bertujuan dalam setiap ekonominya, manusia mampu secara kreatif menemukan solusi demi solusi untuk mengatasi masalah ekonomi.

\subsection{Definisi Ekonomi Managerial}

Ekonomi managerial mengacu kepada aplikasi dari teori ekonomi dan alat analisis dari pengambilan keputusan, untuk mengetahui bagaimana sebuah organisasi dapat mencapai tujuannya dengan efisien. Ekonomi Managerial terintegrasi dalam konsep ekonomi dengan berbagai konsep akuntansi, keuangan dan pemasaran, serta konsep tersebut dimanfaatkan dengan bantuan statistika terutama dalam mengestimasi permintaan (demand) dan perkembangan biaya (cost). Strategi persaingan juga sebagai bagian interdisiplin ilmu dalam pendidikan bisnis. Masalah keputusan dalam manajemen selalu dihadapi oleh sebuah organisasi balik organisasi yang berorientasi profit maupun non profit, dalam usahanya untuk mencapai tujuan dengan kendala tertentu.Termasuk dalam organisasi non profit adalah rumah sakit, badan pemerintah dan perguruan tinggi. Setiap 
organisasi dapat berbeda tujuan dan kendala yang dihadapi, tetapi proses pengambilan keputusan secara mendasar adalah sama.

Fokus dalam mempelajari ekonomi Managerial adalah prinsip dalam mencapai profit. Istilah profit merupakan selisih positif antara penerimaan (revenues) dengan biaya (cost). Untuk perusahaan atau institusi yang non profit kelebihan atau selisih positif antara penerimaan dengan biaya disebut dengan istilah surplus. Kebalikan dari profit disebut dengan rugi (loss), sedangkan kebalikan surplus disebut dengan istilah defisit. Profit merupakan standard pengukuran untuk efektivitas bagi Managerial. Banyak orang berfikir bahwa profit adalah kebutuhan setiap orang dalam mengelola bisnis. Keputusan untuk memproleh profit adalah sesuatu yang tidak bisa dilupakan dalam kondisi dan aktivitas ekonomi normal. Dalam menentukan profit baik bagi bisnis perusahaan perorangan atau perusahaan secara keseluruhan tidak bisa ditentukan oleh pemerintah. Dari pengalaman bisnis, tidak ada pendekatan alternative yang terbaik atau superior alternatif yang dapat digunakan dalam memperoleh profit.

Persaingan dalam memproleh profit untuk perusahaan perseorangan agar dapat memimpin segmen pasar hendaknya berorientasi pada tersedianya keseimbangan barang dan jasa yang berkualitas dengan harga yang diberikan kepada konsumen. Disamping itu, perusahaan perlu memperhatikan produktivitas yang meningkat, pertumbuhan ekonomi yang semakin meningkat dan kondisi ekonomi negara juga cukup baik (Aryaningsih, 2018).

\subsection{Hubungan ekonomi managerial dengan ilmu ekonomi lainnya}

Sebagai ilmu terapan, ekonomi managerial mempunyai kaitan yang erat dengan beberapa ilmu yang lain. Kaitan tersebut dapat digambarkan bahwa teori ekonomi dalam pengambilan keputusan akan memberikan landasan teori 
untuk melakukan peramalan serta penjelasan perilaku ekonomi dengan menggunakan model dalam pengambilan keputusan. Teori ekonomi mikro teruatama berkaitan dengan teori perusahaan Ilmu pengambilan keputusan menyadiakan berbagai macam alat seperti matematika, statistik, ekonometrika yang sangat berguna untuk penyusunan model serta estimasi keputusan, tentu saja dalam upaya pencapaian tujuan dengan cara yang paling efisien. Berbagai area fungsional dari ilmu adimistratif serta Bisnis yang meliputi Akuntansi, keuangan, pemasaran, MSDM serta Produksi, dimana area tersebut menyediakan analisis lingkungan bisnis di mana perusahaan beroperasi.

Dalam teori ekonomi terdapat dua macam teori mikroekonomi dan makroekonomi. Mikroekonomi ialah ilmu yang mempelajari tingkah laku ekonomis secara individual sebagai unit pengambil keputusan seperti konsumen individu, pemilik sumber daya, dan perusahaan bisnis didalam sistem perdagangan bebas. Sedangkan makroekonomi sebaliknya yaitu ilmu yang membahas output, konsumsi, pekerjaan, investasi, dan harga secara keseluruhan atau agregat di perekonomian. Teori ekonomi memprediksi dan menjelaskan prilaku ekonomi yang menjadi faktor penentu yang paling penting atas pengambilan keputusan kualitas dan efektivitas pengambilan keputusan Managerial.

a. Ilmu Keputusan Managerial

Aplikasi teori ekonomi dan perangkat ilmu keputusan untuk memecahkan masalah keputusan Managerial. Solusi optimum untuk masalah keputusan. Ilmu Keputusan :

1. Matematika ekonomi

2. Ekonometri (Statistika)

Matematika ekonomi digunakan untuk memformulakan (menggambarkan dalam bentuk persamaan) model ekonomi yang dipostulatkan dalam teori ekonomi. Dan Ekonometri kemudian menerapkan peralatan ststistik (terutama analisis regresi)pada data 
dunia nyata untuk mengestimasi model yang dipostulatkan oleh teori ekonomi dan digunakan untuk peramalan (forecasting).

Sebagai contoh, teori ekonomi mempostulatkan bahwa kuantitas yang diminta (Q) untuk suatu komositas adalah fungsi yang tergantung pada harga komoditas tersebut $(\mathrm{P})$, pendapatan konsumen $(\mathrm{Y})$, dan harga komoditas lain yang berhubungan yaitu; komoditas komplementer (Pc), dan substitusi (Ps). Bila diasumsikan bahwa selera tidak berubah maka kita dapat mempostulatkan model formal matematika sebagai beikut

$$
\mathrm{Q}=\mathrm{f}(\mathrm{P}, \mathrm{Y}, \mathrm{Pc}, \mathrm{Ps})
$$

Dengan formula diatas kita dapat mengestimasi hubungan empirisnya (ekonometri) yang memungkinkan perusahaan untuk menentukan seberapa besar perubahan Q degan adanya perubahan dalam P, Y, Pc, dan Ps untuk meramalkan permintaan di masa yang akan datang untuk komoditas tersebut agar manajemen dapat mencapai maksud dan tujuan perusahaan (maksimasi laba) dengan cara yang paling efisien.

b. Keterkaitan Dengan Berbagai Area Fungsional Ilmu Administrasi Bisnis

Area fungsional administrasi bisnis meliputi; akuntansi, keuangan, pemasaran, manajemen sumber daya manusia, dan produksi. Jadi ekonomi Managerial merupakan pelajaran yang ruang lingkupnya luas yang menggabungkan teori ekonomi, ilmu pengambilan keputusan, dan area fungsional ilmu administrasi bisnis dan membahas bagaimana ketiga hal tersebut berinteraksi satu sama lain pada saat perusahaan berusaha mencapai tujuannya dengan cara yang paling efisien.Proses yang terkait dengan semua pengambilan keputusan Managerial yang meliputi menetapkan tujuan perusahaan atau organisasi, mendefinisikan masalah yang dihadapi untuk 
mencapai tujuan tersebut, mengidentifikasi berbagai solusi, memilih solusi terbaik dari berbagai solusi yang tersedia dan megimplementasikan keputusan tersebut

Berikut ini akan dijelaskan mengenai alur dari peran ekonomi Managerial dalam proses pengambilan keputusan.

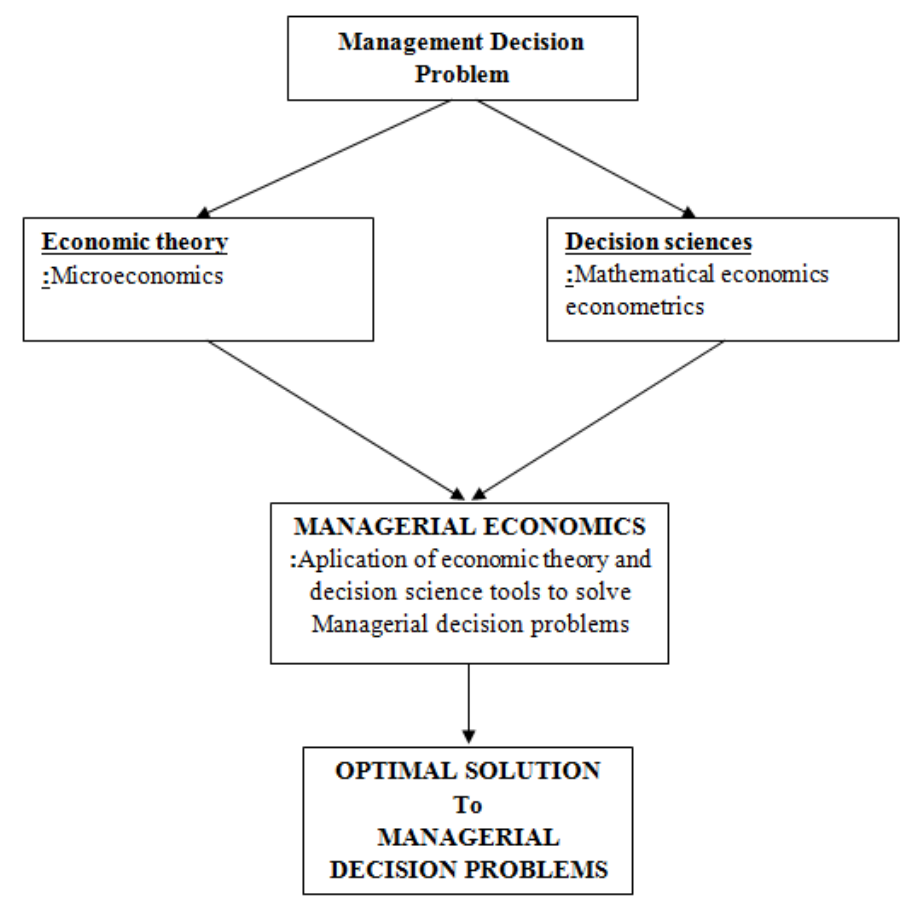

Alur dari peran ekonomi Managerial dalam proses pengambilan keputusan

Sumber: Webster (2003)

\subsection{Prinsip-prinsip Ekonomi Managerial}

Seiring dengan peningkatan pengambilan keputusan, bidang ekonomi menyediakan bahasa umum dan kerangka kerja untuk memahami dan mengkomunikasikan fenomena yang terjadi dalam bisnis, serta antara bisnis dan lingkungannya. Prinsip prinsip dalam ekonomi Managerial membantu dalam penalaran rasional dan pemikiran yang 
jelas. Mereka mengembangkan kemampuan dan kekuatan logis seorang manajer. Beberapa prinsip penting dari ekonomi Managerial meliputi :

a. Prinsip Marginal dan Inkremental

Prinsip ini menyatakan bahwa keputusan dikatakan rasional dan sehat jika diberi tujuan perusahaan untuk memaksimalkan laba, itu mengarah pada peningkatan laba, yang dalam salah satu dari dua skenario :

1. Jika total pendapatan meningkat lebih dari biaya total.

2. Jika total pendapatan menurun kurang dari total biaya.

Analisis marjinal mengimplikasikan penilaian dampak perubahan unit dalam satu variabel di sisi lainnya. Marginal umumnya mengacu pada perubahan kecil. Pendapatan marjinal adalah perubahan total pendapatan per unit perubahan dalam output yang dijual. Biaya marjinal mengacu pada perubahan dalam biaya total per unit perubahan dalam output yang dihasilkan, sementara biaya tambahan mengacu pada perubahan total biaya karena perubahan total output. Keputusan perusahaan untuk mengubah harga akan tergantung pada dampak atau perubahan yang dihasilkan dalam pendapatan marjinal dan biaya marjinal. Jika pendapatan marjinal lebih besar dari biaya marjinal, maka perusahaan harus membawa perubahan harga.

Analisis inkremental berbeda dari analisis marjinal hanya dalam analisis perubahan dalam kinerja perusahaan untuk keputusan Managerial yang diberikan, sedangkan analisis marginal sering dihasilkan oleh perubahan output atau input. Analisis inkremental adalah generalisasi konsep marginal. Ini mengacu pada perubahan dalam biaya dan pendapatan karena perubahan kebijakan, sebagai contoh menambahkan bisnis baru, membeli input baru, memproses produk dan sebagainya. Perubahan dalam output karena perubahan dalam proses, produk atau investasi dianggap sebagai perubahan bertahap. Prinsip inkremental menyatakan bahwa keputusan 